\title{
Protein Intake and Plasma Amino-acids of Infants of Low Birth Weight
}

\author{
H. B. VALMAN, R. J. K. BROWN, T. PALMER, V. G. OBERHOLZER, B. LEVIN
}

British Medical fournal, 1971, 4, 789-791

\section{Summary}

The plasma amino-acid levels in infants of low birth weight fed on expressed human milk and on a proprietary breast-milk substitute, S26, with a protein intake of not more than $4.5 \mathrm{~g} / \mathrm{kg} / \mathrm{day}$ were compared with those in infants fed on an evaporated milk formula whose protein intake ranged from $6 \cdot 15$ to $12.3 \mathrm{~g} / \mathrm{kg} / \mathrm{day}$, as well as with normal infants on normal feeds and protein intake. In general, there was little difference between the levels in infants of low birth weight and in normal infants on the same protein intake. The five infants of low birth weight on high protein intake had generally higher levels of plasma amino-acids compared with the group on the lower protein intake, and in particular the levels of tyrosine, phenylalanine, methionine, and cystathionine could be extremely high. Apart from methionine these high levels may be the result both of a reduction in activity of the enzymes involved in the metabolism of these amino-acids, due to the immaturity of the infant, and of the increased stress of a high protein intake. In view of a possible long-term effect of abnormally high plasma amino-acid levels it is suggested that the protein intake of infants of low birth weight should not exceed $6 \mathrm{~g} / \mathrm{kg} /$ day.

\section{Introduction}

The early feeding of infants of low birth weight to avoid brain damage from hypoglycaemia and hyperbilirubinaemia (Laurance and Smith, 1962; Smallpiece and Davies, 1964; Keitel et al., 1965; Wharton and Bower, 1965) has gained wide acceptance. The higher calorie intake of this regimen induced a more rapid weight gain compared with delayed feeding (Drillien, 1964). In these studies the optimal level of protein intake was not considered, and the tendency since then has been to maintain a higher intake than has been considered normal (Levin et al., 1959; Fomon, 1967).

During an investigation (to be published) by two of us (H.B.V. and R.J.K.B.) of early feeding of infants of low birth weight by continuous intragastric milk feeds, it was noted that those infants having the highest protein intake per $\mathrm{kg}$ of body weight often had positive Guthrie tests. This prompted us to compare the effects of the different protein intakes on the plasma amino-acid levels in infants of low birth weight included in the trial.

\section{Patients and Methods}

Fifteen infants weighing between 1.33 and $2.04 \mathrm{~kg}$ at birth were studied. These were divided into three groups: (1) six infants on

Queen Elizabeth Hospital for Children, London E2 8PS

H. B. VALMAN, M.B., B.CHIR., M.R.C.P., Senior Registrar

R. J. K. BROWN, M.B., B.CHIR., F.R.C.P., Consultant Paediatrician

T. PALMER, B.A., Biochemist

V. G. OBERHOLZER, B.A., Principal Biochemist

B. LEVIN, M.D., F.R.C.PATH., Consultant Pathologist

expressed breast milk having a protein intake of $3.6 \mathrm{~g} / \mathrm{kg} /$ day; (2) four infants fed on S26, a proprietary milk of composition similar to that of breast milk, with a protein intake of $4.5 \mathrm{~g} / \mathrm{kg} /$ day; and (3) five infants on a proprietary half-cream evaporated milk (Regal) with a protein intake of $12.3 \mathrm{~g} / \mathrm{kg} /$ day by the ninth day (Table I). The average gestational age of those in groups 1 and 2 was $35 \cdot 7$ (range 34-37) weeks while for those in group 3 it

TABLE I-Protein Intake (g/kg/day) on the Three Different Milk Feeds

\begin{tabular}{|c|c|c|c|c|c|c|c|c|c|}
\hline Day: & 1 & 2 & 3 & 4 & 5 & 6 & 7 & 8 & 9 \\
\hline \multirow[t]{2}{*}{$\begin{array}{l}\text { Volume of } \\
\text { milk feeds } \\
(\mathrm{ml} / \mathrm{kg} / 24 \mathrm{hr})\end{array}$} & 60 & 90 & 120 & 150 & 180 & 210 & 240 & 270 & 300 \\
\hline & \multicolumn{9}{|c|}{ Protein ( $\mathrm{g} / \mathrm{kg} / 24$ hours) } \\
\hline $\begin{array}{l}\text { Human } \\
\text { S26 } \\
\text { Half-cream }\end{array}$ & $\begin{array}{r}0.72 \\
0.9\end{array}$ & $\begin{array}{l}1.08 \\
1.35\end{array}$ & $\begin{array}{l}1.44 \\
1.80\end{array}$ & $\begin{array}{r}1 \cdot 8 \\
2 \cdot 25\end{array}$ & $\begin{array}{l}2 \cdot 16 \\
2 \cdot 70\end{array}$ & $\begin{array}{l}2.52 \\
3.15\end{array}$ & $\begin{array}{l}2.88 \\
3.60\end{array}$ & $\begin{array}{l}3.24 \\
4.05\end{array}$ & $\begin{array}{l}3.6 \\
4.5\end{array}$ \\
\hline milk & $2 \cdot 46$ & 3.69 & 4.92 & $6 \cdot 15$ & $7 \cdot 38$ & $8 \cdot 61$ & 9.84 & 11.07 & $12 \cdot 3$ \\
\hline
\end{tabular}

was 34.0 (range 32-36) weeks. The mean birth weight of groups 1 and 2 was 1.96 (range $1.67-2.08$ ) $\mathrm{kg}$ and of group 31.84 (range $1 \cdot 33-2 \cdot 04) \mathrm{kg}$. The feed was administered by continuous intragastric drip giving the same daily volume per $\mathrm{kg}$ of body weight to each infant (Table I). Feeding was begun at the age of 4 hours, and in the subsequent 24 hours $60 \mathrm{ml} / \mathrm{kg}$ was given, with daily increments of $30 \mathrm{ml} / \mathrm{kg}$ until a maximum of $300 \mathrm{ml} / \mathrm{kg}$ was attained (Table I). Thereafter the volumes were increased every three days in proportion to the weight.

Free amino-acids in the plasma were determined on picric acid filtrates (Stein and Moore, 1954) by means of a Technicon automatic amino-acid analyser. The usual Technicon procedure had been modified, however, so as to give a reliable estimate of glutamine levels (Palmer, 1968).

\section{Results}

Plasma amino-acid levels from infants of low birth weight in groups 1 and 2 on almost the same protein intake were found to be so similar that they were combined for the purpose of this study. The mean levels from the 10 infants, aged 7 days to 6 weeks old, in this group are given in Table II. No pronounced variation of amino-acid levels over this age period was noted. Included in Table II are the mean plasma amino-acid levels from a series of 12 full-term infants between the ages of 6 days and 3 months receiving a protein intake of up to $6 \mathrm{~g} / \mathrm{kg}$ body weight/day. These levels closely resemble those of the combined groups 1 and 2 .

The mean plasma amino-acid levels from the infants aged 5 days to 6 weeks in group 3 are also given in Table II. In general, higher levels are seen in group 3, and though the differences are small for many amino-acids, for several they are very much greater (Tables II and III, Fig. 2). The most prominent increase occurs in tyrosine, the level of which is up to nine times the maximum level found in groups 1 and 2, and for phenylalanine this ratio is up to five times. The high levels are apparently reached by the fifth to seventh day of life, when the protein intake has risen to $9 \cdot 8 \mathrm{~g} / \mathrm{kg} /$ day (Table I). 
TABLE II-Comparison of Plasma Amino-acid Levels in Infants of Low Birth Weight Fed on Normal Protein Intake (Groups 1 and 2) and on High Protein Intake (Group 3) and in Full-term Infants

\begin{tabular}{|c|c|c|c|c|c|c|}
\hline \multirow{2}{*}{\multicolumn{3}{|c|}{ Amino-acid }} & & \multirow{2}{*}{$\frac{\begin{array}{c}\text { Groups } 1 \text { and } 2 \\
(10 \text { Infants) } \\
7 \text { days-6 weeks }\end{array}}{\begin{array}{c}\text { Mean } \pm \text { S.D. } \\
(\mathrm{mg} / 100 \mathrm{ml})\end{array}}$} & \multirow{2}{*}{\begin{tabular}{|c|}
$\begin{array}{c}\text { Group } 3 . \\
(5 \text { Infants) } \\
5 \text { days-6 weeks }\end{array}$ \\
$\begin{array}{c}\text { Mean t. S.D. } \\
\text { (mg/100 ml })\end{array}$ \\
\end{tabular}} & \multirow{2}{*}{ 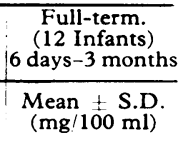 } \\
\hline & & & & & & \\
\hline $\begin{array}{l}\text { Taurine } \\
\text { Hydroxyprolin } \\
\text { Threonine } \\
\text { Serine ... } \\
\text { Asparagine } \\
\text { Glutamine } \\
\text { Glutamic acid } \\
\text { Proline .. } \\
\text { Citrulline } \\
\text { Glycine.. } \\
\text { Alanine } \\
\text { a-Amino-n-but } \\
\text { Valine . . } \\
\text { Homocitrulline } \\
\text { Methionine } \\
\text { Cystathionine } \\
\text { Isoleucine } \\
\text { Leucine } \\
\text { Tyrosine } \\
\text { Phenylalanine } \\
\text { Ornithine } \\
\text { Lysine } \\
\text { Histidine } \\
\text { Carnosine } \\
\text { Arginine }\end{array}$ & 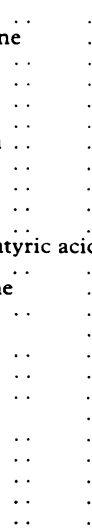 & 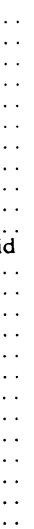 & $\begin{array}{l}\cdots \\
\cdots \\
\cdots \\
\cdots \\
\cdots \\
\cdots \\
\cdots \\
\cdots \\
\cdots \\
\cdots \\
\cdots \\
\cdots \\
\cdots \\
\therefore \\
\therefore \\
\cdots \\
\cdots \\
\cdots \\
.\end{array}$ & $\begin{array}{c}2.10 \pm 0.80 \\
0.77 \pm 0.27 \\
2.40 \pm 0.40 \\
2.90 \pm 0.65 \\
0.50 \pm 0.08 \\
11.1 \pm 1.9 \\
2.40 \pm 0.50 \\
3.85 \pm 1.25 \\
0.36 \pm 0.15 \\
2.20 \pm 0.45 \\
4.15 \pm 0.95 \\
0.22 \pm 0.11 \\
2.95 \pm 0.65 \\
<0.20 \\
0.43 \pm 0.11 \\
1<0.03 \\
1.15 \pm 0.30 \\
2.25 \pm 0.82 \\
2.30 \pm 0.80 \\
1.30 \pm 0.30 \\
2.05 \pm 0.30 \\
3.00 \pm 0.30 \\
1.90 \pm 0.30 \\
1<0.12 \\
1.25 \pm 0.55\end{array}$ & $\begin{array}{r}2.20 \pm 1.05 \\
0.70 \pm 0.24 \\
3.40 \pm 1.00 \\
3.40 \pm 0.30 \\
0.50 \pm 0.16 \\
9.30 \pm 1.40 \\
2.60 \pm 0.75 \\
8.30 \pm 1.55 \\
0.70 \pm 0.32 \\
2.00 \pm 0.45 \\
4.10 \pm 0.45 \\
0.20 \pm 0.07 \\
6.50 \pm 2.05 \\
0.75 \pm 0.14 \\
2.00 \pm 2.05 \\
0.14 \pm 0.10 \\
1.80 \pm 0.55 \\
3.35 \pm 0.70 \\
32.0 \pm 4.5 \\
6.35 \pm 2.15 \\
2.50 \pm 0.45 \\
3.60 \pm 0.60 \\
1.65 \pm 0.25 \\
0.20 \pm 0.16 \\
1.15 \pm 0.25\end{array}$ & $\begin{array}{c}1.75 \pm 1.10 \\
0.46 \pm 0.22 \\
2.20 \pm 0.75 \\
2.45 \pm 0.65 \\
0.51 \pm 0.18 \\
10.1 \pm 1.5 \\
2.30 \pm 0.70 \\
4.20 \pm 1.45 \\
0.23 \pm 0.17 \\
2.05 \pm 0.65 \\
3.85 \pm 1.05 \\
0.22 \pm 0.10 \\
3.95 \pm 1.25 \\
<0.23 \\
0.46 \pm 0.23 \\
<0.02 \\
1.35 \pm 0.45 \\
2.50 \pm 0.65 \\
2.40 \pm 0.75 \\
1.45 \pm 0.50 \\
1.60 \pm 0.45 \\
3.10 \pm 1.05 \\
1.65 \pm 0.30 \\
0.07 \pm 0.17 \\
0.95 \pm 0.45\end{array}$ \\
\hline
\end{tabular}

In only one child in group 3 was the methionine level greatly raised, being 15 times that of the upper limit of groups 1 and 2 , though there was also a significant increase in three of the others.

The plasma cystathionine levels at five to seven days of age for two infants of group 3 were 0.27 and $0.26 \mathrm{mg} / 100 \mathrm{ml}$, whereas the maximum level for the lower protein intake group was only $0.03 \mathrm{mg} / 100 \mathrm{ml}$. Smaller but significant increases were found in two others and thus only one infant having a high protein intake could be considered to have a normal cystathionine level.

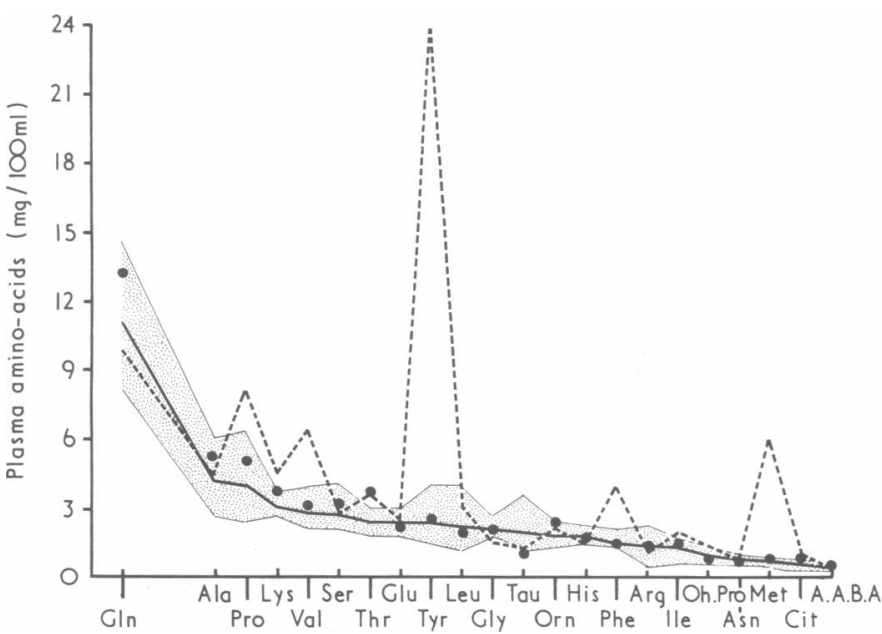

FIG. 1-Plasma aminogram of an infant of low birth weight on high protein intake (broken line) compared with the mean levels (solid line) and the range (shaded area) of groups 1 and 2. The plasma amino-acid levels in the same infant after three days on a normal protein intake are indicated by the solid black dots.
Increased levels of plasma homocitrulline, proline, and valine were also found in infants of group 3 with only slight increases in the levels of lysine, threonine, isoleucine, leucine, and citrulline.

In two of the infants of group 3 the plasma amino-acids were measured both a few days before and a few days after a reduction of protein intake to about $4 \mathrm{~g} \mathrm{~kg}$ /day. The results showed a return to nearly normal levels in each case (Table III, Fig. 1). This pronounced reduction was not due to change with time since in one of these infants the levels four days before reduction of protein intake were very similar to those found in plasma that had been taken a week earlier.

\section{Discussion}

There have been many reports of tyrosyluria, tyrosinaemia, and hyperphenylalaninaemia in neonates, especially in premature infants on high protein intakes (Levine et al., 1939; Woolf and Edmunds, 1950; Bloxham et al., 1960; Hsia et al., 1962; Mathews and Partington, 1964; Dickinson et al., 1970). Infants with tyrosinaemia of prematurity have been investigated for periods up to 43 months of age without any physical or mental ill effects attributable to the tyrosinaemia being found (Partington and Mathews, 1966; Avery et al., 1967; Light et al., 1970). Waisman and Kerr (1967) considered it to be a "disease of prematurity" which was corrected by time, thus making a restricted diet unnecessary.

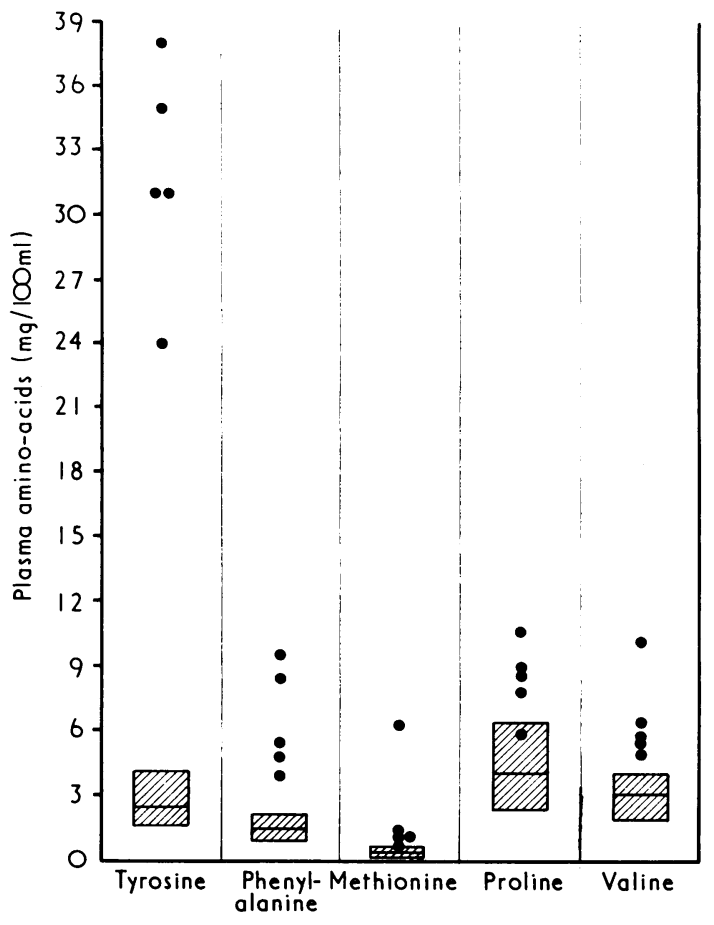

FIG. 2-Levels of five amino-acids in infants of low birth weight on high protein intake. Ranges in groups 1 and 2 are indicated by shaded area.

TABLE III-Effect of High Protein Intake on Levels of Certain Plasma Amino-acids in Five Infants of Low Birth Weight (Group 3)

\begin{tabular}{|c|c|c|c|c|c|c|c|c|c|}
\hline & \multirow{2}{*}{ Baby No. } & \multirow{2}{*}{ Age } & \multicolumn{7}{|c|}{ Plasma Amino-acid Levels (mg/100 ml) } \\
\hline & & & Tyrosine & Phenylalanine & Methionine & Homocitrulline & Cystathionine & Proline & Valine \\
\hline $\begin{array}{l}1 \\
2 \\
3\end{array}$ & $\begin{array}{l}\ldots \\
\cdots \\
\cdots \\
\ldots\end{array}$ & $\begin{array}{l}5 \text { days } \\
7 \text { days } \\
7 \text { days } \\
7 \text { weeks* } \\
5 \text { weeks } \\
6 \text { weeks } \\
7 \text { weeks* } \\
4 \text { weeks } \\
5 \text { weeks* }\end{array}$ & $\begin{array}{r}31 \cdot 0 \\
31 \cdot 0 \\
35 \cdot 0 \\
1.7 \\
33 \cdot 0 \\
24 \cdot 0 \\
2 \cdot 6 \\
38 \cdot 0 \\
4 \cdot 1\end{array}$ & $\begin{array}{l}4.85 \\
9.30 \\
5.30 \\
1.95 \\
4.70 \\
3.90 \\
1.35 \\
8.4 \\
1.75\end{array}$ & $\begin{array}{l}1.05 \\
0.45 \\
0.95 \\
0.43 \\
9.1 \\
6.1 \\
0.71 \\
1.4 \\
0.79\end{array}$ & $\begin{array}{l}0.93 \\
0.65 \\
0.79 \\
0.01 \\
0.44 \\
0.51 \\
0.04 \\
0.78 \\
0.43\end{array}$ & $\begin{array}{l}0.27 \\
0.06 \\
0.26 \\
0.02 \\
0 \\
0.02 \\
0 \\
0.11 \\
0\end{array}$ & $\begin{array}{r}8 \cdot 8 \\
5.8 \\
7.9 \\
5 \cdot 6 \\
4.6 \\
8.4 \\
5.2 \\
10.5 \\
6.6\end{array}$ & $\begin{array}{c}5 \cdot 7 \\
5 \cdot 0 \\
5 \cdot 6 \\
4 \cdot 1 \\
6 \cdot 5 \\
6 \cdot 3 \\
3.05 \\
10 \cdot 0 \\
5 \cdot 1\end{array}$ \\
\hline
\end{tabular}

*Plasma levels following return to a protein intake of less than $4.5 \mathrm{~g} / \mathrm{kg} /$ day. 
Levy et al. (1968, 1969) found a similar apparently benign hypermethioninaemia in 18 infants aged 5-9 weeks who were having at least $7 \mathrm{~g}$ protein $\mathrm{kg}$ day. When this intake was reduced by half, the methionine levels returned to normal. Snyderman et al. $(1968,1970)$ showed hypermethioninaemia to be more pronounced than tryosinaemia in seven babies aged 1-6 months having $9 \mathrm{~g}$ protein $\mathrm{kg}$ day, but the reverse was true in a younger group of premature babies on a similar intake. The only child in our series who had a greatly increased plasma methionine level was indeed the oldest one studied, also indicating that the hypermethioninaemia from a high protein intake develops at a later age than does tyrosinaemia.

The results from our infants, who were all clinically normal, confirm that babies of low birth weight fed more than $6.15 \mathrm{~g}$ protein $\mathrm{kg}$ day will be likely to have markedly raised plasma tyrosine levels together with some increase in the levels of phenylalanine, methionine, and other amino-acids. High levels of plasma cystathionine as found in four out of the five of our infants on high protein feeds, two of whom had levels approaching those observed in cystathioninuria, have not previously been recorded in neonates. Homocitrulline is a constituent of evaporated milk (Gerritsen et al., 1963), which would account for the presence of this amino-acid.

The high levels of plasma tyrosine, phenylalanine, and cystathionine found can be explained by a developmental immaturity of enzyme activity. Liver p-hydroxyphenylpyruvic acid oxidase is deficient in premature babies (Kretchmer et al., 1956, 1957; Kretchmer, 1959) and cystathioninase does not appear in human liver until after birth (Räiha, 1971). Though the methionine-activating enzyme is low in human fetal liver (Räiha, 1971) a possible insufficiency in methionine metabolism as shown by a rise in plasma methionine levels under stress is only apparent after 1 month of age. There may be a developmental change in the metabolism of the sulphur amino-acids at about this time, for taurine, which is abundantly present in the urine of neonates, is found in only trace amounts in the urine of infants aged 1-12 months (Snyderman, 1958). The liver activities of the enzymes for both aromatic and sulphur amino-acid metabolism in infants must be sufficient to cope with the turnover from a "normal" protein intake, as judged by plasma amino-acid levels.

A hereditary condition is well known in which severe hepatic disease and renal dysfunction in infants is accompanied by tyrosinaemia with or without hypermethioninaemia (Zetterström, 1963; Gjessing and Halvorsen, 1965; Perry et al., 1965; Kang and Gerald, 1970) and reduced liver activities of $p$ hydroxyphenylpyruvic acid oxidase (Gentz et al., 1965), the methionine-activating enzyme, and other enzymes (Gaull et al., 1968a, 1968b) have been demonstrated in affected cases. The relationship between the metabolic defects and the severe clinical condition is not clear (Gaull et al., 1970), but it is known that high oral doses of methionine lead to poor growth and widespread organ damage in animals (Perry et al., 1967).

However, no clinical disability has so far been detected in man which could be confidently ascribed to high levels of plasma amino-acids, though a long-term effect cannot be entirely excluded. Results show that a protein intake in excess of $6 \mathrm{~g}$ kg day will lead to abnormally high levels of plasma amino- acids in most if not all infants of low birth weight, and unless it can be shown that such an intake is essential for their well-being, it should be avoided.

We are grateful to Dr. Khulude F. Kandalla for the routine clinical care of these babies and for her help in the trial. We are indebted to John Wyeth and Brother for defraying part of the cost of the investigation. The feeding trials were carried out at the Hackney and Mothers' Hospitals, London.

\section{References}

Avery, M. E., et al. (1967). Pediatrics, 39, 378

Bloxham, H. R., Day, M. G., Gibbs, N. K., and Woolf, L. I. (1960). Biochemical fournal, 77, 320

Dickinson, J. C., Rosenblum, M. D., and Hamilton, P. B. (1970). Pediatrics, 45,606 .

Drillien, C. M. (1964). Growth and Development of the Prematurely Born Infant, p. 304. Edinburgh, Livingstone.

Fomon, S. J. (1967). Infant Nutrition, Philadelphia, Saunders.

Gaull, G. E., Harris, R. C., and Solomon, G. E. (1968a). Pediatric Research, $2,403$.

Gaull, G. E., Rassin, D. K., and Sturman, J. A., (1968b). Lancet, 1, 1318.

Gaull, G. E., Rassin, D. K., Solomon, G. E., Harris, R. C., and Sturman, J. A. (1970). Pediatric Research, 4, 337.

Gentz, J., Jagenburg, R., and Zetterström, R. (1965). Fournal of Pediatrics, 66, 670 .

Gerritsen, T., Vaughn, J. G., and Waisman, H. A. (1963). Archives of Biochemistry and Biophysics, 100, 298.

Gjessing, L. R., and Halvorsen, S. (1965). Lancet, 2, 1132

Gjessing, L. R., and Halvorsen, S. (1965). Lancet, 2, 1132 . England fournal of Medicine, 267, 1067 .

Kang, E. S., and Gerald, P. S. (1970). Fournal of Pediatrics, 77, 397

Keitel, H. G., Menduke, H., Smith, T., and Fiorentino, T. (1965). Pediatric Clinics of North America, 12, 347 .

Kretchmer, N., Levine, S. Z., McNamara, H., and Barnett, H. L. (1956). fournal of Clinical Investigation, 35, 236 .

Kretchmer, N., Levine, S. Z., and McNamara, H. (1957). American fournal of Diseases of Children $\mathbf{9 3}, 19$

Kretchmer, N. (1959). Pediatrics, 23, 606.

Laurance, B. M., and Smith, B. H. (1962). Lancet, 1, 589.

Levin, B., Mackay, H. M. M., Neill, C. A., Oberholzer, V. G., and Whitehead, T. P. (1959). Medical Research Council. Special Report Series, No. 296.

Levine, S. Z., Marples, E., and Gordon, H. H. (1939). Science, 90, 621.

Levy, H. L., Madigan, P. M., MacCready, R. A., and Crawford, J. E. (1968). Fediatric Research, 2, 1302 .

Levy, H. L., et al. (1969). American fournal of Diseases of Children, 117, 96.

Light, I. J., Sutherland, J. M., Friedberg, D. L., and Berry, H. K. (1970). fournal of Pediatrics, 76, 958.

Mathews, J., and Partington, M. W. (1964). Archives of Disease in Childhood, 39, 371 .

Palmer, T. (1968). 6th Colloquium in Amino Acid Analysis, Technicon Monograph, 3, 95. Geneva, Technicon International Division.

Partington, M. W., and Mathews, J. (1966). Fournal of Pediatrics, 68, 749.

Perry, T. L., Hardwick, D. F., Dixon, G. H., Dolman, C. L., and Hansen, S. (1965). Pediatrics, 36, 236.

Perry, T. L., Hardwick, D. F., Hansen, S., Pohlmann, L., and Warrington, P. D. (1967). Fournal of Mental Deficiency Research, 11, 246.

Räiha, N. (1971). Metabolic Processes in the Foetus and Newborn Infant, ed. J. H. P. Jonxis, H. K. A. Visser, and J. A. Troelstra. Leiden, H.E. Stenfert Kroese N.V.

Smallpiece, V., and Davies, P. A. (1964). Lancet, 2, 1349.

Smallpiece, V., and Davies, P. A. (1964). Lance

Snyderman, S. E., Holt, L. E., jun., Norton, P. M., Roitman, E., and Phansalkar, S., H. (1968). Pediatric Research, 2, M., 131 .

Snyderman, S. E., Holt, L. E., jun., Norton, P. M., and Phansalkar, S. V. (1970). American fournal of Clinical Nutrition, 23, 890.

Stein, W. H., and Moore, S. (1954). Fournal of Biological Chemistry, 211, 915.

Waisman, H. A., and Kerr, G. R. (1967). In Amino Acid Metabolism and Genetic Variation, ed. W. L. Nyhan, p. 365. New York, McGraw-Hill.

Wharton, B. A., and Bower, B. D. (1965). Lancet, 2, 969.

Woolf, L. J., and Edmunds, M. E. (1950). Biochemical fournal, 47, 630.

Zetterström, R. (1963). Annals of the New York Academy of Sciences, 111, 220. 